\title{
RESPUESTA DE RATONES INOCULADOS CON BACTERIAS LÁCTICAS DE ORIGEN BOVINO A UN DESAFÍO CON SALMONELLA DUBLIN
}

\author{
Frizzo, L. S. ${ }^{1}$; Peralta, C. ${ }^{2}$; Zbrun, v. ${ }^{1}$; Bertozzi, e. ${ }^{1}$; Soto, L. P. ${ }^{1}$; \\ Marti, e. ${ }^{1}$; Dalla Santina, R. ${ }^{1}$; Sequeira, G. J. ${ }^{1}$ \& Rosmini, M. R. ${ }^{1}$
}

\begin{abstract}
RESUMEN
Salmonella dublin produce un desbalance del ecosistema gastrointestinal de los animales de granja. Algunas bacterias lácticas han mostrado capacidad para contrarrestar los efectos de este patógeno. El objetivo del presente trabajo fue estudiar el efecto protector de un inóculo, formado por 3 cepas de bacterias ácido lácticas (BAL) de origen bovino, en ratones desafiados con Salmonella dublin DSPV595T, mediante la observación de lesiones micromorfológicas patognomónicas producidas por el agente patógeno. El microorganismo patógeno se inoculó a 2 grupos de ratones convencionales, uno de los cuales fue previamente tratado con el inóculo BAL. El estudio histopatológico se realizó tanto en los animales que murieron espontáneamente después de haber sido desafiados con el patógeno, como en aquellos que sobrevivieron después de 24 días de haber recibido la Salmonella. El $50 \%$ de los animales que pertenecieron al grupo control murieron espontáneamente mientras que en el grupo tratado con BAL esa cifra alcanzó el 32\%. Sólo un 10\% de las hembras tratadas con BAL murieron espontáneamente mientras que en los machos esa cifra alcanzó al 46,7\%. Todos estos individuos presentaron lesiones típicas. El tratamiento con el inóculo brindó protección a los ratones inoculados con Salmonella dublin DSPV 595T en la etapa en la cual se produjeron las muertes espontáneas. Las hembras resultaron mejor protegidas que los machos.
\end{abstract}

Palabras clave: bacterias lácticas, Salmonella dublin, protección de ratones.

\section{SUMMARY}

\section{Response of mice inoculated with lactic acid bacteria of bovine origin experimentally challenged with Salmonella dublin.}

Salmonellosis is a disease that causes a disorder in the gastrointestinal ecosystem of farm animals. Some lactic acid bacteria have shown capacity to counteract the effects of this pathogen. The aim of this work was to study the protecting effect of an inoculum, formed by three lactic acid bacteria (LAB) strain of bovine origin, in mice challenged with Salmonella dublin DSPV595T, through the

1.- Departamento de Salud Pública Veterinaria (DSPV). Facultad de Ciencias Veterinarias, UNL. Kreder 2805. (3080) Esperanza, provincia de Santa Fe.Email: lfrizzo@fcv.unl.edu.ar 2.- Laboratorio de Cito e Histopatología. FCV (UNL).

Manuscrito recibido el 30 de agosto de 2005 y aceptado para su publicación el 13 de octubre de 2005. 
observation of micro-morphological pathognomonic lesions produced by the pathogenic agent. The pathogenic microorganism was inoculated to two conventional mice groups, having been one of them previously treated with the LAB inoculum. Histopathological studies were performed on both animals that spontaneously died after being challenged with the pathogen and animals that survived 24 days after receiving Salmonella. Fifty percent of control group animals died spontaneously vs. $32 \%$ in the group treated with LAB. Only $10 \%$ of females treated with LAB died spontaneously whereas within males the number reached $46,7 \%$. All animals showed typical lesions. The treatment with the inoculum protected mice that were inoculated with Salmonella dublin DSPV 595T at the stage when spontaneous deaths occured. Females were better protected than males.

Key words: lactic bacteria, Salmonella dublin, mice protection. 